\title{
The Common Strategies of Students in Learning Oracy in Academic Context Subject
}

\author{
Winny Berliana* \\ English Department, FBS Universitas Negeri Padang, Padang, Sumatra Barat 25131, Indonesia \\ Email: winnysyahdin@gmail.com
}

\begin{abstract}
The purpose of this study was to find the common strategies used by students in learning Oracy at English Department in Universitas Jambi. There were six participants from 001, 002 and 003 class. In addition, a qualitative design, case study approach and interviews are used in this study to collect and analyze the data. Then, the researcher found six learning strategies: social, compensation, metacognitive, affective, cognitive, and memory strategies based on Oxford. The result told that most students used some strategies in Oracy class. In several conditions, many students used selfefficacy, and they used gestures to increase their confidence in Oracy class. They liked to repeat the new vocabulary and then remembered several words. Moreover, the effect of this study was the students might get the suitable strategies in Oracy class and for the teachers, it could be the matter of knowledge to teach the compatible methods to make they got the comprehension in Oracy class, and also for the future researchers could also observe about what strategies students did in Oracy class, according to the types of student's competence.
\end{abstract}

Keywords: Students' Strategies, Learning, Oracy

\section{INTRODUCTION}

Speaking and listening are fundamental elements of social interaction as in [1], [2], [3] have explained. By utilizing listening and speaking skills, students build interaction with each other. Therefore, Wilkinson [4] emphasized the ability to use the oral skills of speaking and listening which he called oracy. In the Faculty of Teacher Training and Education, Oracy in Academic Context subject was firstly implemented in the 2018/2019 academic year. Nevertheless, based on a simple interview that the researcher did with the students, they encountered difficulties in learning Oracy in Academic Context class such as less of focus in listening to the topic, lack of vocabulary, lack of expression in speech, hard to understand speech and difficulties in processing information as ideas to convey. Relating to the difficulties, those were necessary to apply learning strategies in oracy. By knowing the strategies in Oracy class, these facilitated students to learn more successful in the process of learning and helped the students in reaching the target and solving their problem in the learning process. Based on the phenomenon, the researcher interested in investigating the strategies that students used in learning Oracy in Academic Context.

\section{REVIEW OF RELATED LITERATURE}

Oracy is a branch of communicative skills instruction which combines listening and speaking in its learning and teaching process. Oracy could be simplified into two theories. First, oracy is referred to as the ability to understand the meaning of spoken language as Wilkinson have stated. Second, oracy is interpreted as students' speaking skills which are the result of student self-confidence when delivered their argument as stated in Millard [5]. The brief description above pointed out the core definition of oracy, oracy is a branch of communicative skills instruction which combines listening and speaking in its learning and teaching process. On the other hand, in the Syllabus for Oracy in Academic Context course in 2018 of English Department students in Universitas Jambi stated that this course is based on performance, with an emphasis on verbal ability to conveyed understanding ideas, as well as to listened, and responded to other people's spoken languages fluently and correctly.

In addition, to beat the troubles in Oracy class, the understudies required a few strategies. O'Malley, and Chamot argued learning strategies were exceptional contemplations or practices that people use to help them grasp, learn, or know new data [6]. It is explicit activities taken by students to help their own learning, to make the learning simpler, quicker, more agreeable, more selfcoordinated, more compelling and more adaptable. Thus, Language learning systems assume a significant function during the time spent learning the language as Oxford argued.

Therefore, learning strategies as techniques, approaches or deliberate actions that students took in order to facilitate the learning and recalled of both 
linguistic and content area information. By employing the right strategies, the process of learning the language could improve significantly. Therefore, Wilkinson [7] stated that there are social, compensation, metacognitive, affective, cognitive, and memory strategies

\section{METHODS}

In this research, the researcher used qualitative research. The researcher used a qualitative research because this research aimed to investigate students' strategies in Oracy in Academic context class by interviewing them to get information in a detail understanding and report the information in description. The design of this research is case study. Case study as an approach by focusing attention on a case intensively and in-depth investigation with a clear explanation. This study took place in English Department in Universitas Jambi and used purposive sampling. The participants involved six students from Class 001, 002, and 003, each class representative consisted of two students. To collect the data, the researcher used interview and in analyzing the data, the researcher used several steps according to Cresswell [8].

\section{FINDINGS AND DISCUSSION}

This section presented the findings of common learning strategies of students in Oracy class. The researcher found that in memory, students liked to looking up the dictionary and memorizing the word, in cognitive, students preferred to watching English movies, listening and singing English song and also reading an English books, newspapers or articles. In addition, in affective, students liked to doing selfefficacy, using gestures and giving self-rewarding and in metacognitive, students preferred to highlighting the important information.

Meanwhile, in compensation, students preferred to repeating the words or sentences and in social, students liked to asking question to friends or lectures, practicing with friends and also discussing in group work. Furthermore, there were some common learning strategies that they used in Oracy class, they were selfefficacy in studying (affective), using gestures (affective), repeat the words (compensation) and memorize the new vocabulary (memory).

\subsection{Self-efficacy}

Bandura argued that self-efficacy is somebody's conviction on abilities to do a task to accomplish indicated objectives [9]. It concerns more with what they can do instead of what aptitudes they have. In Oracy class, S3 used self- efficacy even though she stated that if she tried to improve self- efficacy by exercising by herself, she felt even more nervous because the topic was hard for her.

"When I just practiced by myself I thought my performance was good but I felt nervous because the topic was hard for me, so, the result was not really good" (S3)

On the other hand, S1, S2, S4, S5, S6 totally agreed that self-efficacy helped them in improving their skills in Oracy class. S4 for example said before she went to campus, shetried to exercise her speech in front of the mirror until she thought that was pretty good and ready to practice in Oracy class.

"Sometimes I stand in front of mirror to practice my gesture, and listen to my pronunciation because I have no friends to practice with" (S4)

In a classroom context, an understudy who accepts that his exhibition is kindness be roused to strive to get great outcomes. Another statement on self-efficacy is given by Cubukcu [10]. He said that self-efficacy is identified with understudies' learning commitment which involves their conduct, intellectual capacity, and learning inspiration. It is an appropriate technique in exercise speaking and listening in Oracy class. In reality, students needed to self-efficacy in learning speaking and listening, because they thought that is the way for them to improve their skills in Oracyclass.

\subsection{Using gestures to increase confidence}

All the participants in this study agreed that one of the strategies they used to improve their confidence in Oracy class, was to use gestures. As S2 opinion, she used gestures while she was performing her speech made her more relax to speak in front of her friends. S3 also mentioned that she used gestures to manage her nerve, while S1 and S6 stated that by using gestures, they believed their friends would enjoy her performance better.

"Gestures made me not toneless in front of my friends, and made me more relax"(S2)

"When I spoke in front of my friends with gestures, they were more understand to what I said" (S6)

Hornby (2006) in Farlianti [11] clarified that gestures or body language is the way toward conveying what we are feeling or thinking, we spot and move our body instead of by words. The understudies consistently use signal to cause their discussion pleasant when they to communicate with one another. To help this, Kendon [12] expressed that speakers utilize the gestures in such a way as to make something that is being said more exact 
or unwind. Therefore, it can be concluded that gesture is a way that helps students to communicate better, the recipient can clearly understand and comprehend what is conveyed. It helped to improve speaking and listening ability in Oracy class.

\subsection{Repeating the words or sentences}

Interview results showed that all of the participants repeated the word or sentences in improving correct pronunciation in Oracy class.

"I usually repeat the words that I have learned, because I wanted to pronounce the words or sentences well in speaking in Oracy class" (S2)

Doff opined that repetition of the words or sentences are utilized to acclimate understudies with a particular structure standard articulation [13]. Reiteration is the least complex drill utilized in learning language designs. Students simply rehashed what the teachers said or the recording device produces. This might be utilized for the introduction of new words and would be valuable for speaking and listening class. In conclusion, repetition enables students to be aware of the relationship between forms, meaning, the use of language and also helped students to memorize the words or phrases which they can use in speaking in Oracy class.

\subsection{Memorizing meaning and new words}

From the interview, S6 believed that by memorizing the words and meaning that she has looked up from dictionary, she did not have to reopen the dictionary, because she has remembered the words. S2, S4, and S5 have the same opinions, they looked up the dictionary because they often found unfamiliar words and always tried to memorize them, so, it was easier to use them again in daily conversation. $\mathrm{S} 1$ and $\mathrm{S} 3 \mathrm{did}$ not look up the dictionary, but they memorized new words and its meaning to use in Oracy class.

"I always tried to use every difficult word to my daily conversation, but if the word rarely used in daily conversation, I just kept in my note and I just make my own example " $(\mathrm{S} 3)$

In point of view from Richard and Platt [14], "Memorizing is the process of establishing information in memory. The term 'memorizing' usually refers to conscious processes." This implies the students use memorization deliberately and they consider the cycle of remembrance when they are applying it. In addition, according to the findings reported by Cortazzi \& Jin in M. Alam [15], most of the Chinese students are still using memorizing method from some vocabulary books and dictionaries as the primary means of learning vocabulary. In Oracy class, it also important to memorize meaning that has been look up from dictionary, because it assisted understudies with improving their capacity to talk in English

\section{CONCLUSION}

Intention of present research is to find the common learning strategies that English students used in Oracy in Academic Context class. After doing the research and analysis, the researcher concluded students in Oracy class used 4 (four) common strategies. First, they did selfefficacy. They practiced speaking and listening by themselves at home. Second, they also used gestures in speaking in Oracy class, they felt gestures could make their friends more understand about what they said, beside their friends only listened. Third, students repeated the new words that they got from listening to English songs, watched English movies and read English books, newspapers or articles. Fourth, students memorized the new words, and they could use them in Oracy class. So, these common strategies helped students in improving their speaking and listening skills in Oracy class.

\section{SUGGESTION}

The researcher suggested students to use strategies that are appropriate for them to understand speaking and listening skills in Oracy class, so that they can understand the lesson easier and try to get the other strategies if the previous strategies unsuitable to use in process of learning oracy. Furthermore, lecturers need to find out interesting ways of teaching speaking and listening skills in Oracy class, so that, the students are easier to comprehend speaking and listening skills in Oracy in Academic Context class. In addition, the other researchers can investigate the learning strategies that are rarely used by English students in Oracy class. The other researchers also can investigate the effectiveness of certain categories of learning strategies that students used in Oracy class. Besides, the researcher also suggests that other researchers can conduct the research about the differences between learning techniques used by the high achievement English students and the lower achievement English students in Oracy class

\section{REFERENCES}

[1] K. Johnson, K.E. Morrow, Communication in The Classroom: Handbooks for Teachers' series, London: Longman, 1981.

[2] Goga, and Sulaiman, "Improving the Speaking Skill of the First Year Students of SMK 1 Polewali Using Questioning Techniques", Unpublished Thesis. Makassar, Graduate Program UNM, 2004.

[3] A.P. Gilakjani, and N.N. Sabouri, 'Learners' listening comprehension difficulties in English language 
learning: A literature review", English Language Teaching, 9 (6), 123-133, 2016.

[4] A. Wilkinson, The Implication of Oracy, 20 (2). 112. doi: $10.1080 / 0013191680200205,1968$.

[5] W. Millard, "Speaking up: The importance of oracy in teaching and learning", Voice 21, 2016.

[6] J. O'Malley, and A. Chamot, Introduction. In Learning Strategies in Second Language Acquisition (Cambridge Applied Linguistics, pp.1 15), Cambridge: Cambridge University Press. doi: 10.1017

/CBO9781139524490.003, 1990.

[7] R.L. Oxford, Language Learning Strategies: What Every Teacher Should Know, Boston: Heinle \& Heinle, 1990.

[8] J.W. Creswell, Qualitative inquiry \& Research design: Choosing among five approaches (2nd ed.),Thousand Oaks. CA: Sage, 2007.

[9] A. Bandura, In self-efficacy: The exercise of control. New York: Freeman, 1997.

[10] F. Cubukcu, "A Study of the correlation between self-efficacy and foreign language learning anxiety", Journal of Theory and Practice in Education, 4(1), 148- 158, 2008.

[11] A.N. Farlianti, et al, "The Analysis Of Gesture Used By The Students Of English Study Program In The Classroom Interaction At The University Of Sembilan belas November." Kolaka, Education: Journal of Education, 2 (2). 202-214. ISSN : 2579, 8383, 2017.

[12] A.Kendon, Language and Gesture: Unity or Duality? UK: Cambridge University Press, 2000. 162-185. 2000.

[13] A. Doff, Teach English: A Training Course for Teachers, Cambridge: Cambridge University Press in association with the British Council, 1990.

[14] J. C. Richards, J. Platt and Platt, H, Dictionary of Language Teaching and Applied Linguistics, Harlow, England: Longman Group U.K. Limited, 1992.

[15] M. Alam, "Learning Vocabulary at Tertiary Level: Strategies, Techniques and Materials", The Online Journal of New Horizon, 8 (3), 109- 117. 2018. 